\title{
New bird remains from the Middle Eocene of Guangdong, China
}

\author{
Min Wang, Gerald Mayr, Jiangyong Zhang, and Zhonghe Zhou \\ Acta Palaeontologica Polonica 57 (3), 2012: 519-526 doi: http://dx.doi.org/10.4202/app.2011.0061
}

Wedescribe a new avian taxon (Sanshuiornis zhangi gen. et sp. nov.) from Middle Eocene black oil shales in the Huayong Formation of Guangdong Province, south China. The specimen consists of a distal tibiotarsus and a complete foot with tarsometatarsus and pedal digits in articulation. A preliminary phylogenetic analysis does not resolve the affinities of the fossil, but the bones show resemblances to some "ciconiiform" birds. The peculiar hypotarsus morphology, which is block-like and exhibits four cristae, resembles that of the early Eocene Rhynchaeites, which is a stem group representative of the Threskiornithidae. The new Chinese fossil has, however, proportionally longer legs than Rhynchaeites and its phylogenetic affinities probably cannot be resolved without further material.

Key words: Aves, Ciconiiformes, Threskiornithidae, Middle Eocene, China.

Min Wang [wangmin nju@163.com], Jiangyong Zhang [zhangjiangyong@ivpp.ac.cn ], and Zhonghe Zhou [zhonghe@yeah.net], Key Laboratory of Evolutionary Systematics of Vertebrates, Institute of Vertebrate Paleontology and Paleoanthropology, Chinese Academy of Sciences, and Graduate University of Chinese Academy of Sciences, Beijing 100044, China; Gerald Mayr [Gerald.Mayr@ senckenberg.de], Forschungsinstitut Senckenberg, Sektion Ornithologie, Senckenberganlage 25, 60325 Frankfurt am Main, Germany.

This is an open-access article distributed under the terms of the Creative Commons Attribution License (for details please see creativecommons.org), which permits unrestricted use, distribution, and reproduction in any medium, provided the original author and source are credited. 
Full text $(736.5 \mathrm{kB})$ 
